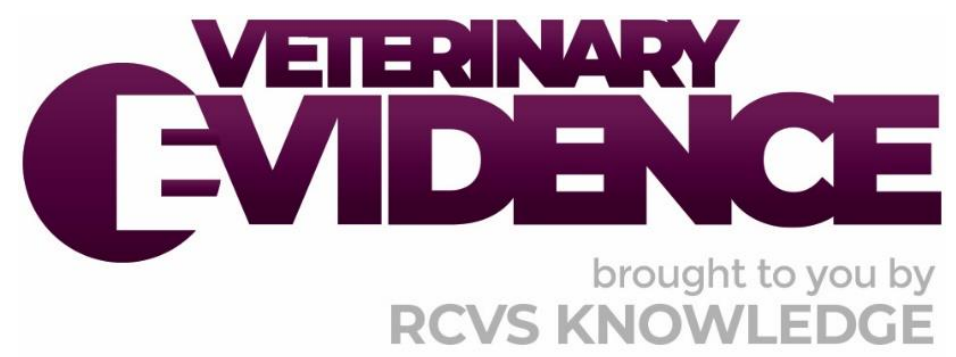

\title{
In canine acute diarrhoea with no identifiable cause, does daily oral probiotic improve the clinical outcomes?
}

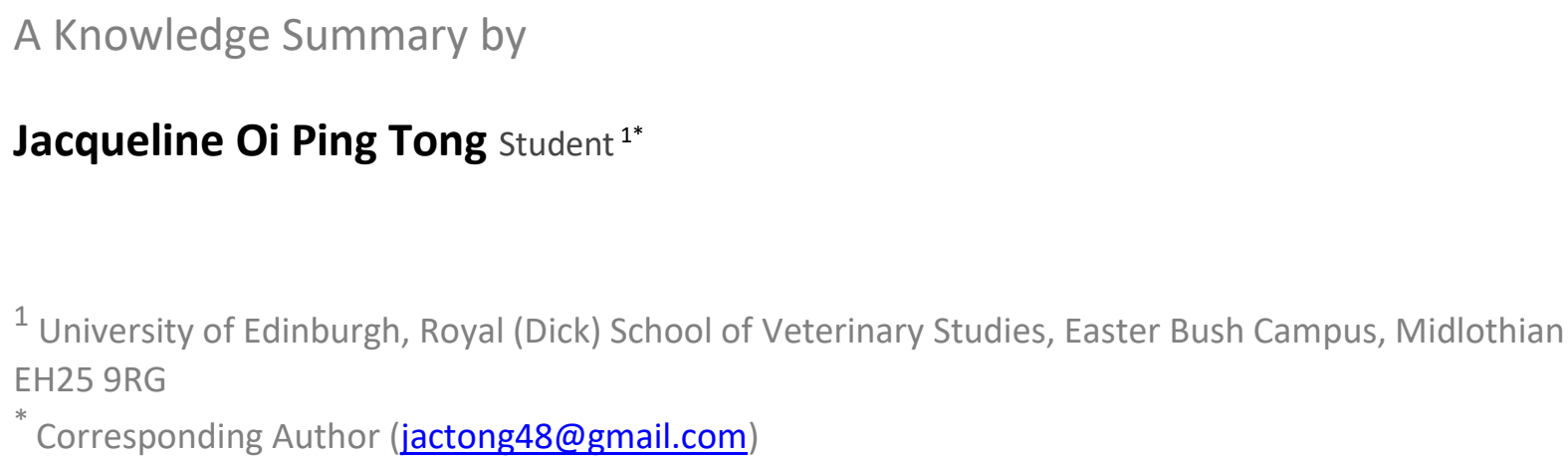

There is an erratum to this paper published in Veterinary Evidence Vol 5, Issue 4 (2020): 10.18849/VE.V5I4.437

ISSN: 2396-9776

Published: 09 Jan 2018

in: Vol 4, Issue 4

DOI: 10.18849/VE.V4I4.252

Reviewed by: Myra Forster-van Hijfte (CertVR CertSAM

DipECVIM-cA FRCVS) and Adam Swallow (BVSc MRCVS)

Next Review Date: May 20th 2021 


\section{KNOWLEDGE SUMMARY}

There is an erratum to this paper published in Veterinary Evidence Vol 5, Issue 4 (2020): html PICO question

In canine acute diarrhoea with no identifiable cause, does a daily probiotic supplement in diet, compared to no probiotic supplement, provide better clinical outcomes?

\section{Clinical bottom line}

Five placebo-controlled trials suggested a daily oral probiotic supplement provides better clinical outcomes to dogs that have acute diarrhoea (present $<14$ days) without an identifiable cause. However, the strength of the evidence is limited and there is uncertainty around the clinical relevance of the studies to some of the outcomes. The probiotic agents, dose, dosing interval, the feeding methods, diets and the duration of treatment were varied in these studies. These variations can lead to different clinical outcomes.

\section{Clinical scenario}

A dog with acute diarrhoea has been brought to your clinic and no cause is identified. The owners suggest the feeding of a probiotic to shorten the recovery time, based on their findings on the Internet. You have no experience in recommending a probiotic supplement as diarrhoea management. You wish to find out if the suggestion is scientifically supported.

\section{The evidence}

Five randomised, blinded, placebo-controlled trials (Herstad et al., 2009; Kelley et al., 2009; Ziese et al., 2018; Gomez-Gallego et al., 2016; and Nixon et al., 2019) have been found fully or partially relevant to the PICO. The trials studied the effects of probiotic use on indices of the clinical improvement of acute diarrhoea with no identifiable cause. They measured the time to diarrhoea resolution (Herstad et al., 2009; Kelley et al., 2009; and Nixon et al., 2019), improvement in diarrhoea severity (Ziese et al., 2018 and Gomez-Gallego et al., 2016), change in faecal microbiota (Ziese et al., 2018 and Gomez-Gallego et al., 2016) and the percentage of dogs requiring additional medical treatment, e.g. antibiotics (Kelley et al., 2009 and Nixon et al., 2019). Currently, there is no clear definition of acute diarrhoea. However, diarrhoea is classified as chronic when it lasts constantly, or intermittently for more than 14 days (Chandler, 2002). Based on the description of chronic diarrhoea, diarrhoea lasting less than 14 days is described as 'acute' in this Knowledge Summary. 


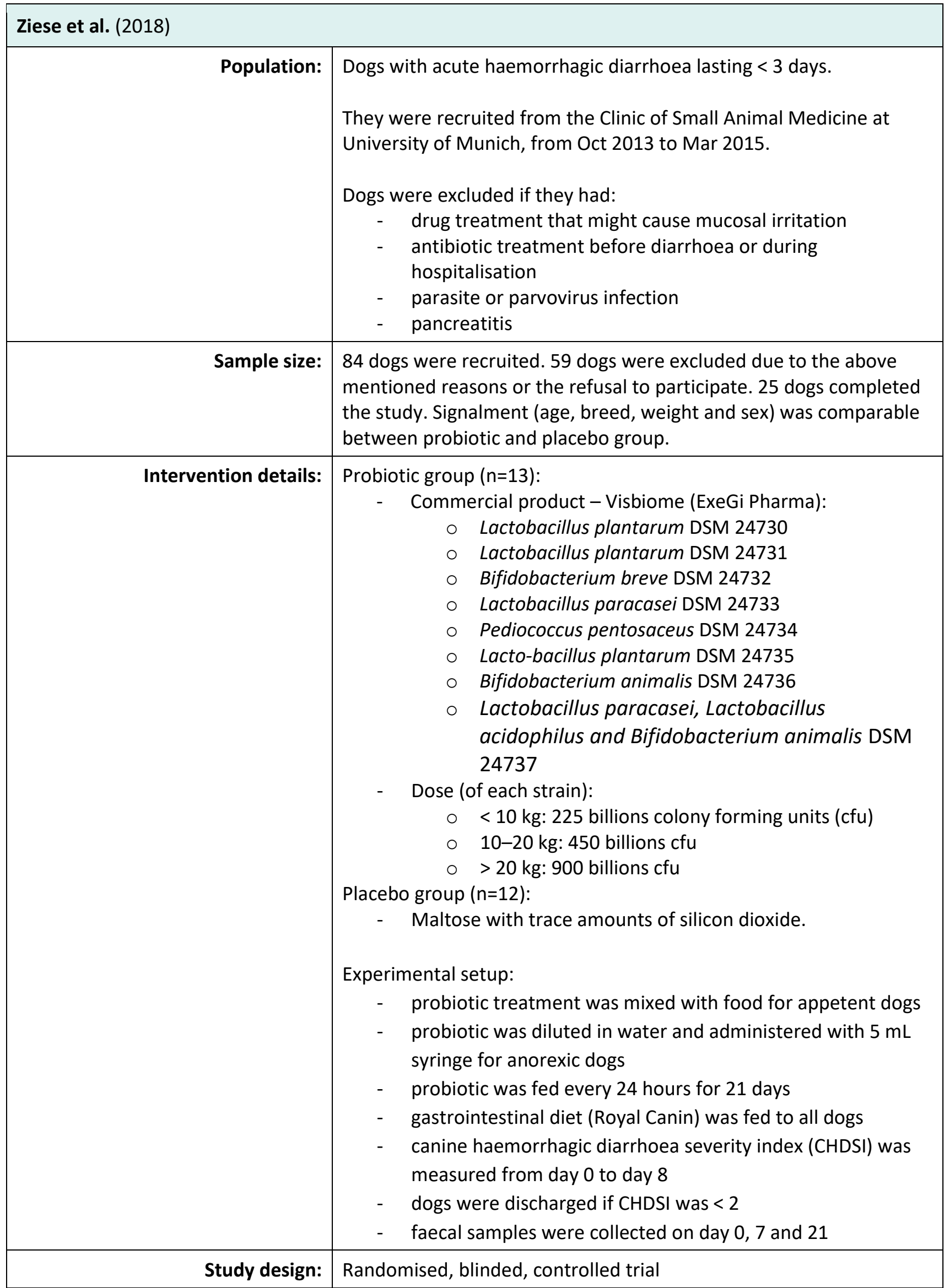




\begin{tabular}{|c|c|c|}
\hline Outcome studied: & & 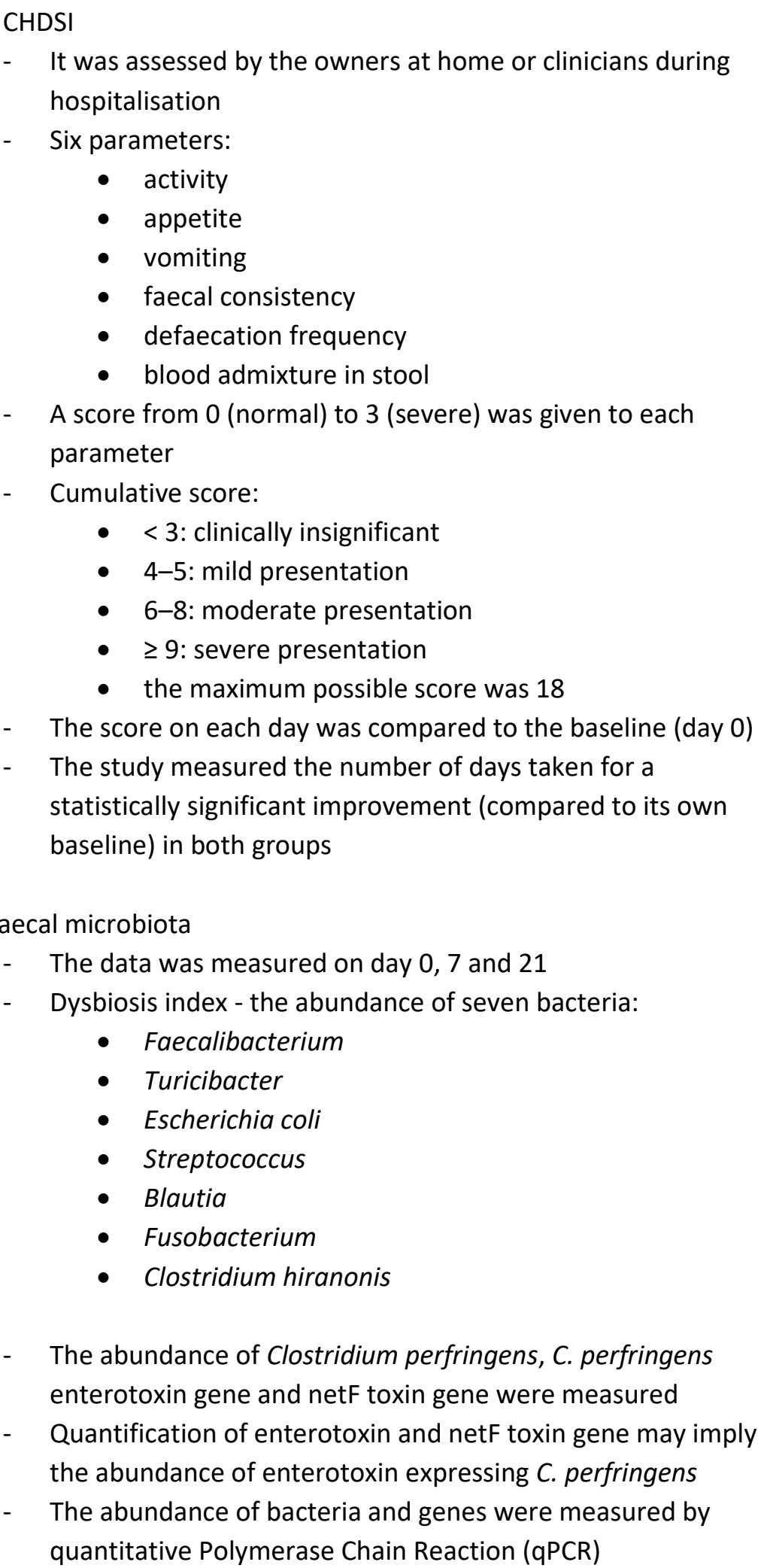 \\
\hline $\begin{array}{l}\text { Main findings: } \\
\text { (relevant to PICO question): }\end{array}$ & 1. & $\begin{array}{l}\text { CHDSI } \\
\text { - In the probiotic group, a statistically significant improvement } \\
\text { was observed on day } 3 \text {, compared to its own baseline (day } \\
\text { 0) (mean: } 5.0 \text {, standard deviation (SD): } 3, P=0.008 \text { ). A } \\
\text { statistically significant improvement was not observed until } \\
\text { day } 4 \text { in the placebo group, compared to its own baseline } \\
\text { (mean: } 5.2, S D: 2.8, P=0.002 \text { ). }\end{array}$ \\
\hline
\end{tabular}




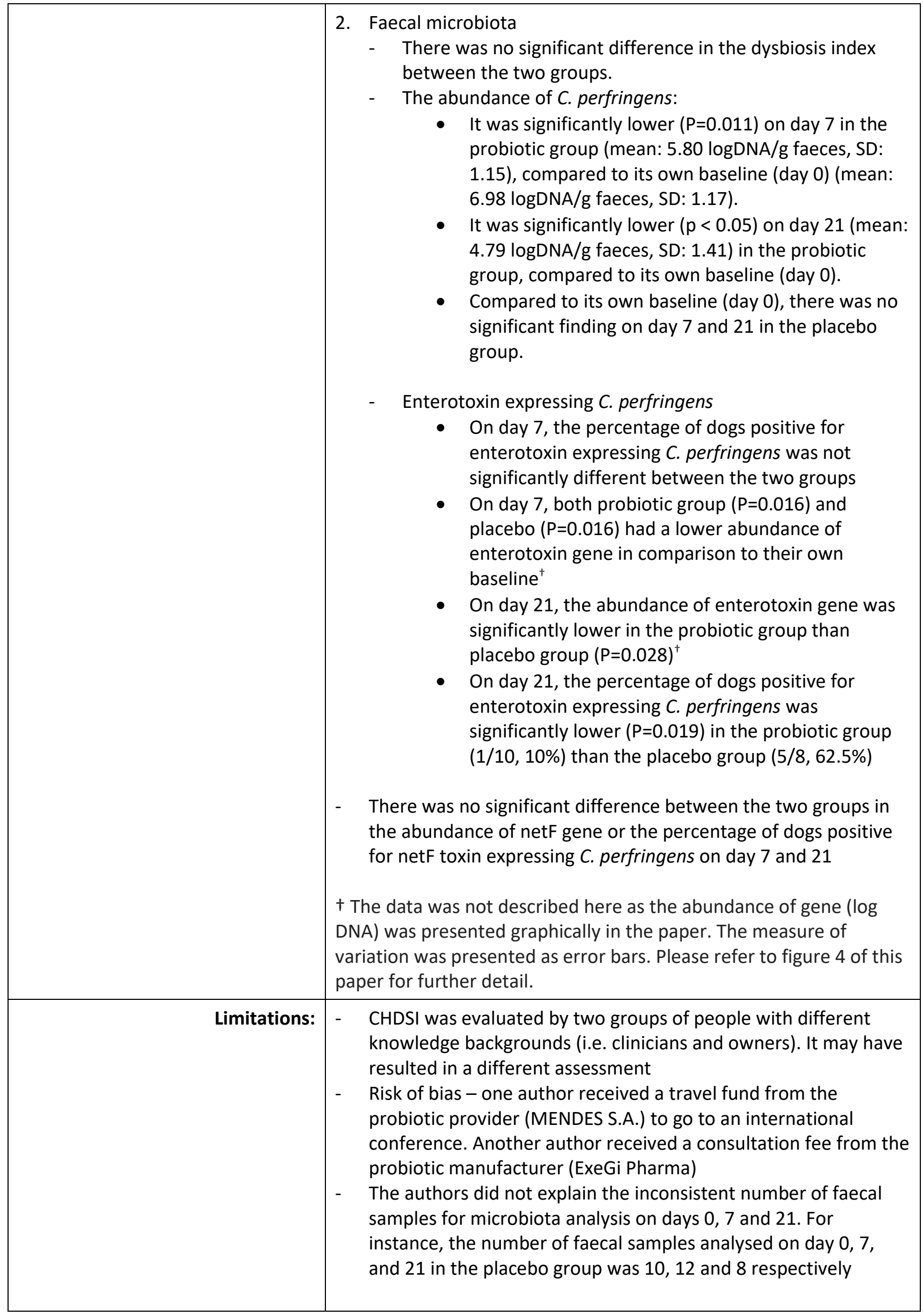




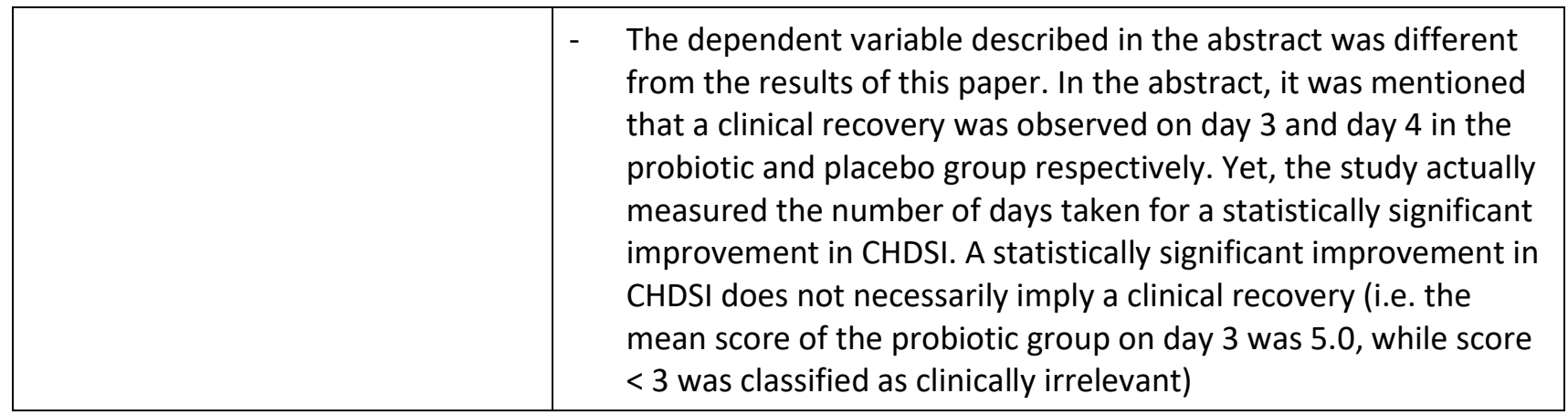

Gomez-Gallego et al. (2016)

\begin{tabular}{|c|c|}
\hline Population: & $\begin{array}{l}\text { Dogs } \geq 6 \text { months old with acute diarrhoea. } \\
\text { They were recruited from clinics in southern Finland. } \\
\text { Dogs were excluded if they had: } \\
\text { - } \quad \text { systemic illnesses } \\
\text { - } \quad \text { diarrhoea lasting } \geq 2 \text { weeks } \\
\text { - } \quad \text { hypoproteinaemia } \\
\text { - } \quad \text { antibiotic or corticosteroid treatment } 30 \text { days prior to the trial } \\
\text { - } \quad \text { recurrent vomiting } \\
\text { - } \quad \text { Giardia infection } \\
\text { - } \quad \text { probiotic administration or new medication, other than the } \\
\text { - } \quad \text { veterinary visit for diarrhoea medications other than the } \\
\text { experimental probiotic product during the study }\end{array}$ \\
\hline Sample size: & 66 dogs were recruited. 44 dogs completed the study. \\
\hline Intervention details: & $\begin{array}{l}\text { Probiotic group ( } \mathrm{n}=25 \text { ): } \\
-\quad 2 \mathrm{dL} \text { sour-milk probiotic product daily } \\
\text { - } \quad 2 \times 10^{9} \text { cfu of each of the following strains: } \\
\text { - Lactobacillus fermentum VET 9A } \\
\text { - Lactobacillus rhamnosus VET 16A } \\
\text { - } \quad \text { Oactobacillus plantarum VET 14A } \\
\text { two feeding times, or administer it in one feeding time } \\
\text { Placebo group ( } \mathrm{n}=19 \text { ): } \\
\text { - Sterilised water with } 10 \% \text { titanium (I.V) oxide (Sigma-Aldrich, } \\
\text { Finland) } \\
\text { Experiment set-up: } \\
\text { - The participants visited one of the five study clinics in } \\
\text { southern Finland to receive the test product } \\
\text { - The treatment period was } 7 \text { days, with a 6-month follow-up } \\
\text { period } \\
\text { Treatment period: } \\
\text { - The diet consisted of a low-fat protein source (e.g. } \\
\text { chicken, fish) and rice }\end{array}$ \\
\hline
\end{tabular}




\begin{tabular}{|c|c|}
\hline & $\begin{array}{l}\text { - The participants visited the same vets on day } 0 \text { and day } 7 \\
\text { - The vets filled in a questionnaire on the physical exam } \\
\text { for each visit } \\
\text { - Faecal samples were collected on day } 0 \text { and day } 7 \\
\text { - The owners filled in a validated questionnaire (Roine, } \\
\text { Uusitalo and Hielm-Björkman., 2016) on stool } \\
\text { consistency each day } \\
\text { - 6-month follow-up period: } \\
\text { - The dogs gradually returned to their normal diet } \\
\text { - The owners filled in a questionnaire on recurrence of } \\
\text { diarrhoea and other gastrointestinal signs, on day } 14,21 \text {, } \\
28 \text { and at } 6 \text { months }\end{array}$ \\
\hline Study design: & Randomised, blinded, controlled trial \\
\hline Outcome studied: & $\begin{array}{l}\text { 1. Stool consistency (Waltham Faecal Scoring System) } \\
\text { - } \quad \text { From } 1 \text { (very hard stool) to } 5 \text { (watery diarrhoea) } \\
\text { - } \quad \text { The score was measured on day } 0-7,14,21,28 \\
\text { 2. Faecal microbiota } \\
\text { - The abundance of: } \\
\text { - C. perfringens (alpha toxin or enterotoxin expressing } \\
\text { - } \quad \text { strain) } \\
\text { - Enterohaemorrhagic E. Coli/ Enteropathogenic } \text { E. Coli } \\
\text { - Enterococcus faecium } \\
\text { - S. aureus } \\
\text { - Total eubacteria } \\
\text { The faecal samples were collected and measured on day } 0 \\
\text { and by qPCR }\end{array}$ \\
\hline \multirow[t]{3}{*}{$\begin{array}{l}\text { Main findings: } \\
\text { (relevant to PICO question): }\end{array}$} & $\begin{array}{l}\text { 1. Stool consistency } \# \\
\text { - Compared to day } 0 \text {, the mean score was reduced by } 1.712 \text { in } \\
\text { the probiotic group and } 1.279 \text { in the placebo group on day } \\
\text { 7. The difference was statistically significant }(P=0.043) \\
\text { - During the first month post-treatment, the average } \\
\text { reduction in the mean stool consistency score in the } \\
\text { probiotic group was greater than the placebo group, with a } \\
\text { difference of } 0.271(P=0.033)\end{array}$ \\
\hline & $\begin{array}{l}\text { 2. Faecal microbiota }{ }^{\#} \\
\text { - The decrease in the number of } C \text {. perfringens alphatoxin } \\
\text { producing strain }(\mathrm{P}=0.05) \text { and } E \text {. faecium }(\mathrm{P}=0.032) \text { was } \\
\text { greater in the probiotic group than the placebo group, with } \\
\text { statistical significance } \\
\text { - The mean changes in the other bacteria from day } 0 \text { to day } 7 \\
\text { were not statistically significant }\end{array}$ \\
\hline & $\begin{array}{l}\text { \# The measure of variation was reported graphically as error bars in } \\
\text { the paper. Please refer to figure } 1 \text { (stool consistency) and figure } 2 \\
\text { (faecal microbiotia) for further detail. }\end{array}$ \\
\hline
\end{tabular}




\begin{tabular}{|c|c|}
\hline Limitations: & $\begin{array}{l}\text { The paper did not evaluate the baseline variations in age, sex, } \\
\text { breed and weight between the two groups } \\
\text { - The administration frequency (once daily or split into two } \\
\text { feedings) were not tightly controlled in this study } \\
\text { - The author intended to collect data on day } 14,21,28 \text { and at } 6 \\
\text { months to evaluate the diarrhoea recurrence and other } \\
\text { gastrointestinal signs. However, no data at } 6 \text { months was } \\
\text { presented } \\
\text { It was not explicitly clear on how the authors executed two of } \\
\text { the exclusion criteria - i.e. how they kept track of whether the } \\
\text { participants had veterinary visits for other diarrhoea medication, } \\
\text { or received medications and probiotics other than the } \\
\text { experimental product during the study }\end{array}$ \\
\hline
\end{tabular}

\begin{tabular}{|c|c|}
\hline \multicolumn{2}{|l|}{ Herstad et al. (2009) } \\
\hline Population: & $\begin{array}{l}\text { Dogs with acute gastroenteritis and diarrhoea. } \\
\text { They were recruited from the small animal clinic at the Norwegian } \\
\text { School of Veterinary Science. } \\
\text { Dogs were excluded if they: } \\
\text { - } \text { had clinical signs for } \geq 2 \text { weeks } \\
\text { - } \text { received a probiotic } 1 \text { month before the trial } \\
\text { - required supportive therapy during hospitalisation }\end{array}$ \\
\hline Sample size: & 36 dogs \\
\hline Intervention details: & 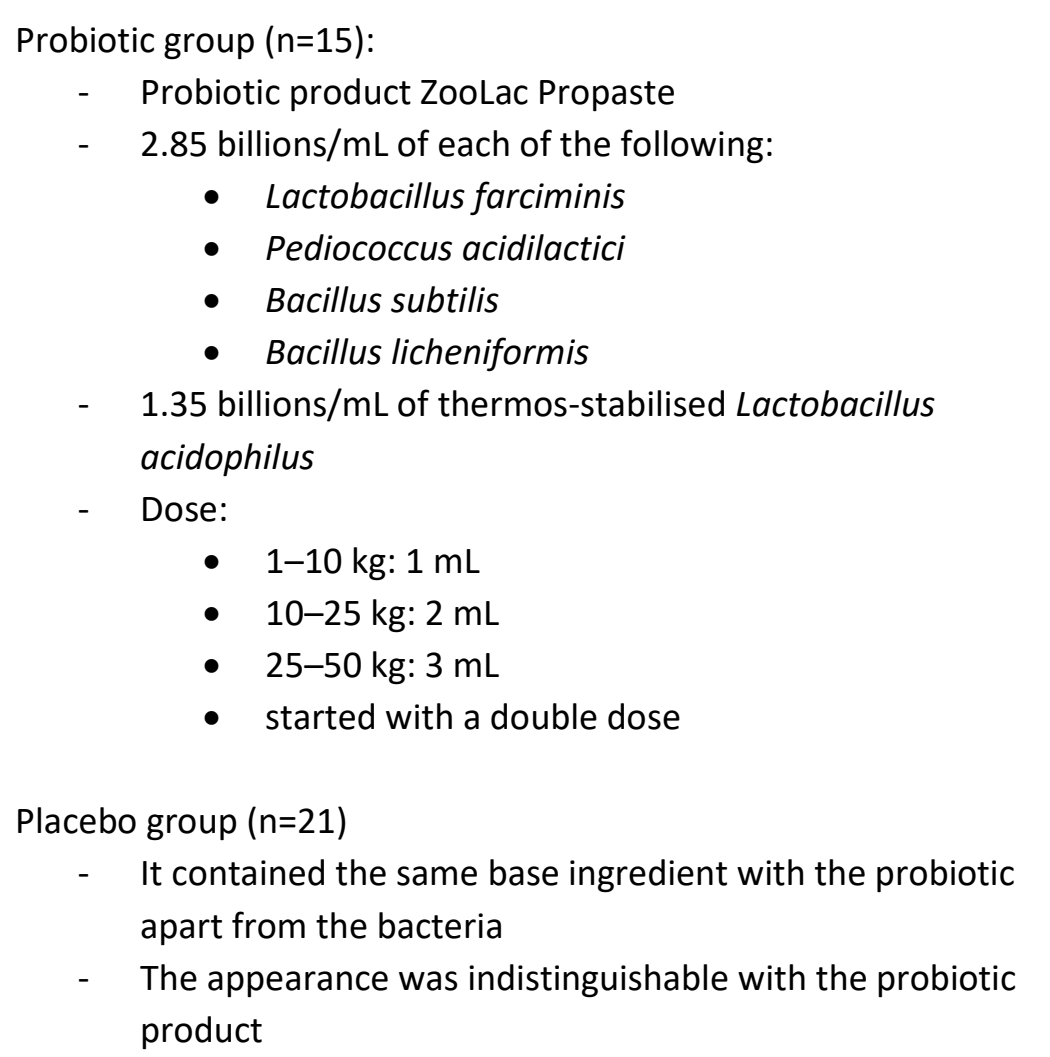 \\
\hline
\end{tabular}




\begin{tabular}{|c|c|}
\hline & 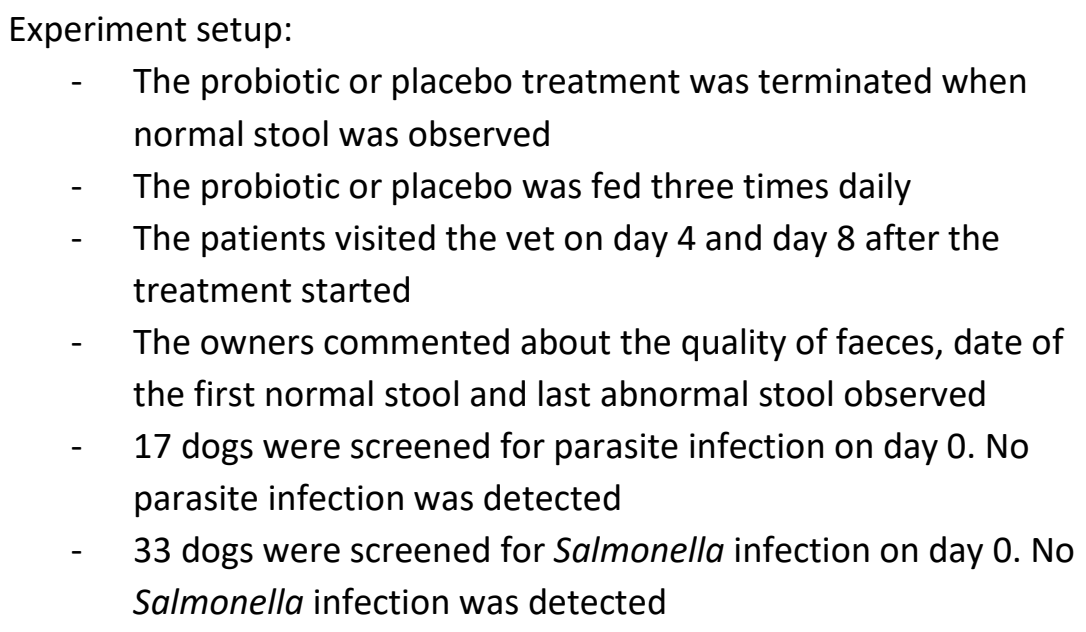 \\
\hline Study design: & Randomised, blinded, controlled trial \\
\hline Outcome studied: & $\begin{array}{l}\text { 1. The time from day } 0 \text { to the last abnormal stools observed } \\
\text { 2. The time from day } 0 \text { to the first normal stools observed } \\
\text { 3. Number of stools during the first three days of the treatment }\end{array}$ \\
\hline $\begin{array}{l}\text { Main findings: } \\
\text { (relevant to PICO question): }\end{array}$ & $\begin{array}{l}\text { 1. A shorter time from day } 0 \text { to the last abnormal stools }(\mathrm{P}=0.045) \\
\text { was reported in the probiotic group (mean: } 1.3 \text { days, } 95 \% \mathrm{Cl} \text { : } \\
0.5-2.1 \text { days) than the placebo group (mean: } 2.2 \text { days, } 95 \% \mathrm{Cl} \text { : } \\
\text { 1.3-3.1 days) } \\
\text { 2. There was no statistically significant difference between the } \\
\text { probiotic (mean: } 2.9 \text { days, } 95 \% \mathrm{Cl}: 2.1-3.7 \text { days) and the placebo } \\
\text { (mean: } 3.4 \text { days, } 95 \% \mathrm{Cl}: 2.6-4.2 \text { days) from day } 0 \text { to first normal } \\
\text { stool } \\
\text { 3. The number of stools was reduced in both groups during the } \\
\text { first three days ( } \mathrm{P} \leq 0.01 \text { ). No descriptive data (e.g. the mean } \\
\text { number of reduction and measure of variation) was provided. } \\
\text { The difference between groups was not statistically significant }\end{array}$ \\
\hline Limitations: & $\begin{array}{l}\text { The paper did not evaluate the baseline variation in age, sex, } \\
\text { breed and weight between the two groups } \\
\text { - In the evaluation of clinical signs before the trial, the number } \\
\text { of respondents did not add up to } 36 \text { (sample size) in the } \\
\text { categories of fever ( } n=29) \text {, appetite }(n=34) \text {, change in diet } \\
\text { ( } n=34) \text {, antiparasitic treatment }(n=35) \text {, vaccination }(n=35) \text { and } \\
\text { consumption of spoiled food ( } n=35) \text {. The author did not explain } \\
\text { the inconsistent number of respondents } \\
\text { - Single-centre study } \\
\text { - Faecal analyses on parasite and Salmonella infection before the } \\
\text { trial were not performed in } 19 \text { dogs and three dogs } \\
\text { respectively } \\
\text { Nine dogs in the probiotic group and four dogs in the placebo } \\
\text { group consumed spoiled food before the trial. This may } \\
\text { complicate the aetiologies of the diarrhoea of the participating } \\
\text { dogs } \\
\text { The paper did not state explicitly who were blinded in the trial. } \\
\text { No clear and standardised definition of 'abnormal stool' was } \\
\text { provided to the owners and clinicians }\end{array}$ \\
\hline
\end{tabular}




\begin{tabular}{|c|c|}
\hline \multicolumn{2}{|l|}{ Kelley et al. (2009) } \\
\hline Population: & $\begin{array}{l}\text { Young adult dogs with acute diarrhoea and no other medical } \\
\text { condition. } \\
\text { They received no prior treatment and were referred to vet clinics. }\end{array}$ \\
\hline Sample size: & $\begin{array}{l}45 \text { dogs were recruited and } 31 \text { dogs completed the study. } \\
\text { Signalment (age, breed and weight) of the probiotic and placebo } \\
\text { group was comparable. }\end{array}$ \\
\hline Intervention details: & $\begin{array}{l}\text { Probiotic group ( } \mathrm{n}=13 \text { ): } \\
\text { - } \quad \text { Bifidobacterium animalis } \mathrm{AHC7}, 1 \times 10^{10} \mathrm{cfu} / \mathrm{dose} \\
\text { Placebo group ( } \mathrm{n}=18 \text { ): } \\
\text { - } \text { Same vehicle as the probiotic without the bacterium } \\
\text { Experiment setup } \\
\text { - } \quad \text { All dogs were screened for Giardia and intestinal parasite } \\
\text { infection } \\
\text { - } \quad \text { All dogs routinely received ivermectin or pyrantel to control } \\
\text { internal parasites } \\
\text { - } \quad \text { Treatment was administrated as a cocoa butter treat, twice } \\
\text { daily } \\
\text { - Treatment was administrated for a maximum of } 2 \text { weeks or } \\
\text { until the resolution of diarrhoea } \\
\text { - Both groups received Eukanuba or lams maintenance diet } \\
\text { - Trained kennel staff monitored the behaviour and recorded } \\
\text { the stool score daily } \\
\text { - The administration of metronidazole was based on the } \\
\text { following considerations: } \\
\text { - number of abnormal stools } \\
\text { - degree of diarrhoea } \\
\text { - overall health } \\
\text { - risk of outbreak to the neighbouring dogs }\end{array}$ \\
\hline Study design: & Randomised, blinded, controlled trial \\
\hline Outcome studied: & $\begin{array}{l}\text { Time to diarrhoea resolution } \\
-\quad \text { Stool score } \\
\bullet \quad 1 \text { = ideal } \\
-2 \text { = soft } \\
-3=\text { viscous liquid with some particulate matter } \\
-4=\text { watery } \\
-\quad \text { Diarrhoea resolution } \\
-\quad \text { score improved from } 4 \text { to } \leq 2 \text {, and } \\
\text { - } \text { remained at } \leq 2 \text { for at least } 5 \text { consecutive days } \\
\text { Percentage of dogs administered metronidazole during the study }\end{array}$ \\
\hline
\end{tabular}




\begin{tabular}{|c|c|}
\hline $\begin{array}{l}\text { Main findings: } \\
\text { (relevant to PICO question): }\end{array}$ & 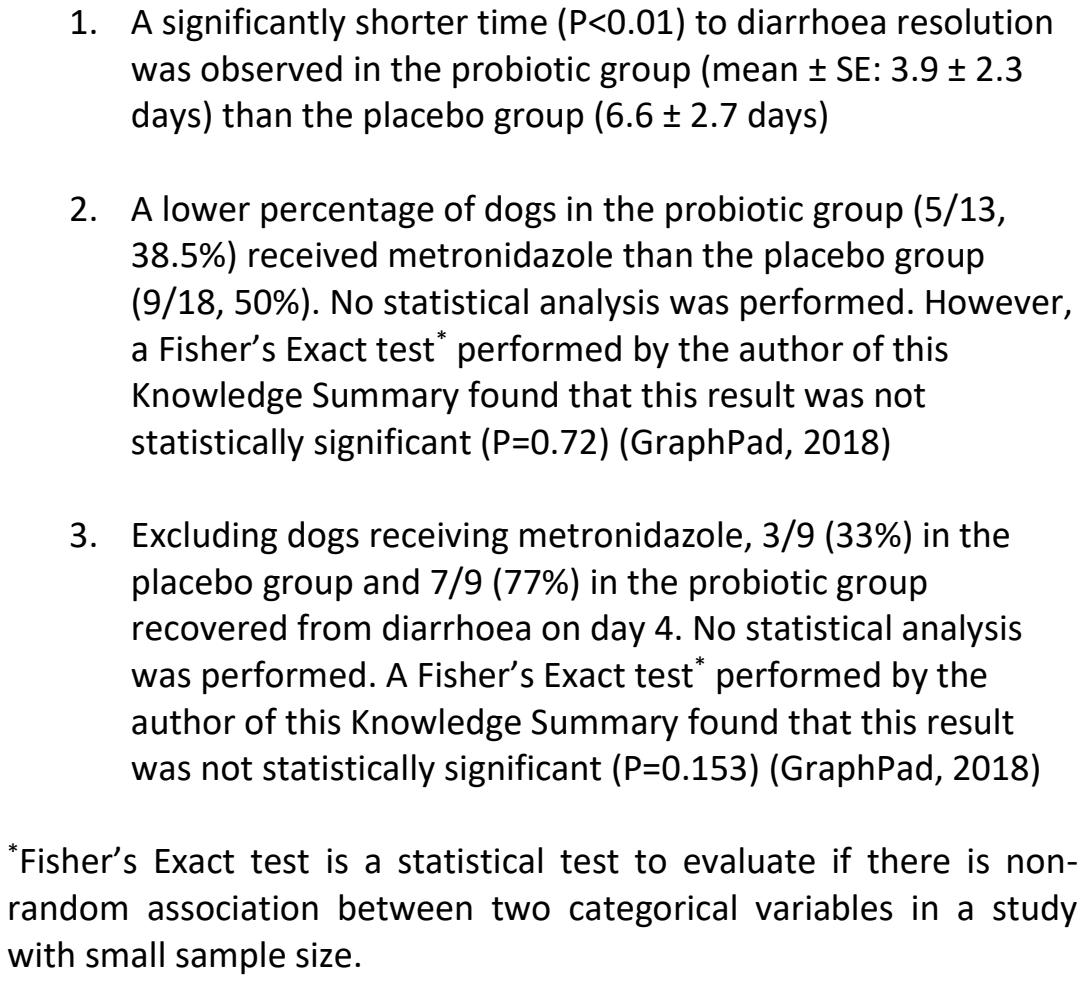 \\
\hline Limitations: & $\begin{array}{l}\text { - Dogs were recruited from one organisation only } \\
\text { - } \quad \text { Only one probiotic bacterium was included in the study } \\
\text { percentage of dogs receiving metronidazole between the } \\
\text { two groups } \\
\text { - No statistical analysis was performed on the different } \\
\text { percentage of dogs (without metronidazole treatment) } \\
\text { recovered on day } 4 \text { between the probiotic and placebo } \\
\text { group } \\
\text { An error in data presentation was suspected in the main } \\
\text { findings (see point 3). The number of dogs in the probiotic } \\
\text { group should be eight instead of nine, after the exclusion of } \\
\text { the five dogs receiving metronidazole } \\
\text { - Three dogs were identified as Giardiasis positive during the } \\
\text { study. They continued the study and their data was included } \\
\text { The stool scoring system was not validated as it had no } \\
\text { reference } \\
\text { The definition of acute diarrhoea (i.e. the duration of } \\
\text { diarrhoea) was not specified in this study } \\
\text { The use of cocoa butter is not recommended due to the risk } \\
\text { of theobromine toxicity }\end{array}$ \\
\hline
\end{tabular}

Nixon et. al (2019)

Population: Dogs who had a faecal score of 5 or 6 (watery stool) for $\geq$ one occasion within 24 hours before the veterinary visit.

They were recruited from 11 units in the UK and three units in Ireland. 


\begin{tabular}{|c|c|}
\hline & 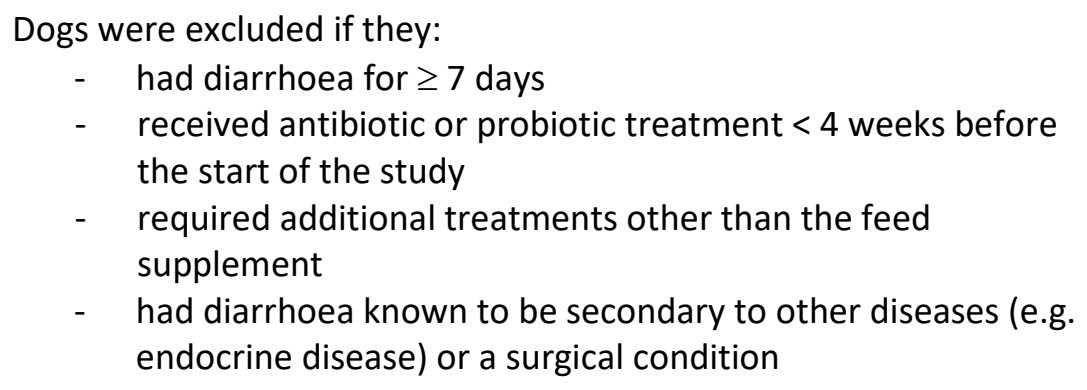 \\
\hline Sample size: & $\begin{array}{l}148 \text { dogs were recruited. } 30 \text { dogs were excluded due to dosing error, } \\
\text { failure to accept the study diet or inappropriate inclusion (i.e. no } \\
\text { recorded diarrhoea). } 118 \text { dogs were included in the study. } \\
107 \text { dogs completed the study with diarrhoea resolution. } 11 \text { dogs } \\
\text { were withdrawn for additional medical intervention. Signalment } \\
\text { (age, breed, weight, and sex) were comparable between the two } \\
\text { groups. }\end{array}$ \\
\hline Intervention details: & $\begin{array}{l}\text { Probiotic group ( } \mathrm{n}=57 \text { ): } \\
\text { - } \quad \text { E. faecium } 4 \mathrm{~b} 1707,2 \times 10^{8} \mathrm{cfu} / \mathrm{g} \\
\text { Probiotic paste (Pro-Kolin Advanced) with Preplex prebiotic, } \\
\text { combined kaolinite and montmorillonite clay, psyllium, } \\
\text { pectin, and beta glucan } \\
\text { - } \quad \text { Two dogs were withdrawn for additional medical } \\
\text { treatments. } 55 \text { dogs completed the study } \\
\text { Placebo group ( } \mathrm{n}=61 \text { ): } \\
\text { - } \quad \text { Oral paste with indistinguishable taste, packaging and } \\
\text { appearance } \\
\text { - Nine dogs were withdrawn for additional medical } \\
\text { treatments. } 52 \text { dogs completed the study } \\
\text { Experimental setup } \\
\text { - All dogs received Hills i/d } \\
\text { - Probiotic and placebo paste was administrated orally every } 8 \\
\text { hours } \\
\text { The treatment was terminated on day } 10 \text { or when the dogs } \\
\text { had normal defaecation consecutively three times } \\
\text { - Dose: } \\
\bullet \quad<5 \mathrm{~kg}: 2 \mathrm{ml} \\
\bullet \quad 2-15 \mathrm{~kg}: 3 \mathrm{ml} \\
\bullet \quad 15-30 \mathrm{~kg}: 5 \mathrm{ml} \\
\bullet \quad 30-45 \mathrm{~kg}: 7 \mathrm{ml} \\
\text { Dogs with deterioration or no improvement were withdrawn } \\
\text { from the study and were given additional medical } \\
\text { intervention }\end{array}$ \\
\hline Study design: & Randomised, blinded, controlled trial \\
\hline Outcome studied: & $\begin{array}{l}\text { 1. Duration of diarrhoea } \\
\text { - It was measured from the start of the first probiotic or } \\
\text { placebo treatment to diarrhoea resolution }\end{array}$ \\
\hline
\end{tabular}




\begin{tabular}{|c|c|}
\hline & $\begin{array}{l}\text { - Diarrhoea was resolved when the dogs had normal } \\
\text { defaecation three times consecutively } \\
\text { - } \quad \text { Faeces with a consistency score } \leq 3 \text { was defined as normal. } \\
\text { - The faecal consistency score was based on the } \\
\text { - It ranged from } 1 \text { (firm) to } 6 \text { (watery) } \\
\text { - Dogs withdrawn for additional medical treatments were } \\
\text { censored from the analysis for the duration of diarrhoea } \\
\text { 2. Rate of diarrhoea resolution } \\
\text { - It measured the proportion of dogs with diarrhoea against } \\
\text { time (hours) } \\
\text { 3. Additional medical intervention } \\
\text { - It measured the percentage of dogs withdrawn for the } \\
\text { additional treatment }\end{array}$ \\
\hline $\begin{array}{l}\text { Main findings: } \\
\text { (relevant to PICO question): }\end{array}$ & $\begin{array}{l}\text { 1. The probiotic group (median: } 32 \text { hours, range: } 2-118 \text { hours, } \\
n=51 \text { ) had a significantly shorter duration of diarrhoea }(\mathrm{P}=0.008) \\
\text { than the placebo group (median: } 47 \text { hours, range: } 4-167 \text { hours, } \\
\mathrm{n}=58 \text { ). The inter-quartile range was reported in the box plot } \\
\text { (figure } 3 \mathrm{~B} \text { of the paper) } \\
\text { 2. Probiotic group had a } 1.6 \text { times faster rate of resolution than } \\
\text { placebo group ( } \mathrm{P}=0.02 \text { ) } \\
\text { 3. A significantly }(\mathrm{P}=0.04 \text { ) lower percentage of dogs in the probiotic } \\
\text { group }(3.5 \%, 2 / 57) \text { required additional medical treatments than } \\
\text { the placebo group }(14.8 \%, 9 / 61 \text { ) }\end{array}$ \\
\hline Limitations: & $\begin{array}{l}\text { - Although dogs with diarrhoea secondary to other diseases or } \\
\text { surgical conditions were excluded, the other causes of } \\
\text { diarrhoea, such as viral and parasitic infection, were not } \\
\text { investigated before the trial } \\
\text { - } \\
\text { Risk of bias - one author is employed by the probiotic } \\
\text { manufacturing company (Protexin) } \\
\text { - The number of dogs completed the study did not match with the } \\
\text { number of dogs included in the analysis for the duration of } \\
\text { diarrhoea. For instance, } 52 \text { dogs in the placebo group completed } \\
\text { the study, and } 58 \text { dogs were involved in the analysis for the } \\
\text { duration of diarrhoea }\end{array}$ \\
\hline
\end{tabular}


Five placebo-controlled studies (Herstad et al., 2009; Kelley et al., 2009; Ziese et al., 2018; Gomez-Gallego et al., 2016; and Nixon et al., 2019) have assessed the clinical outcomes of administering a daily oral probiotic supplement in dogs that have acute diarrhoea with no identifiable cause. The significant findings were reported for various outcome measures, namely the time to diarrhoea resolution (Herstad et al., 2009; Kelley et al., 2009; and Nixon et al., 2019), improvement in diarrhoea severity (Gomez-Gallego et al., 2016 and Ziese et al., 2018), change in the microbiota (Gomez-Gallego et al., 2016 and Ziese et al., 2018) and the percentage of dogs that required additional treatment (Nixon et al., 2019 and Kelley et al., 2009).

Herstad et al. (2009), Kelley et al. (2009) and Nixon et al. (2019) presented a shorter time to diarrhoea resolution in the probiotic group. The improvement ranged from 15 hours (Nixon et al., 2019) to 2.7 days (Kelley et al., 2009). All three studies were partially relevant to the PICO due to several reasons. Herstad et al. (2009) did not perform faecal analyses on 19 dogs and three dogs for parasite and Salmonella infection. The study also included dogs with spoiled food consumption. Meanwhile, although dogs with diarrhoea secondary to other diseases or surgical conditions were excluded, Nixon et al. (2019) did not investigate the other potential causes of diarrhoea in the participants, such as viral and parasitic infection. Thereby, it is uncertain if there was no identifiable cause of all the cases of diarrhoea in these two studies. Kelley et al. (2009) spotted three dogs were Giardiasis positive during the trial and included their data. It reduces the relevance of this study because not all of the participants suffered from diarrhoea with no known cause.

The limitations of these three studies (Herstad et al., 2009; Kelley et al., 2009; and Nixon et al., 2019) reduce the strength of the presented evidence. For example, Herstad et al. (2009) did not evaluate the baseline variations, such as sex, age and breed, between the probiotic and placebo group. The potential variations in signalment can lead to confounding analysis. No standardised definition of abnormal stool was given to the owners and clinicians, which may reduce the reliability. A competing interest is identified in Nixon et al. (2019). The study was at risk of bias, and double-blinding was applied to reduce the associated risk. However, there was a mismatch between the number of dogs that completed the study and the number of dogs included in the analysis of diarrhoea resolution. The authors did not explain the discrepancy. Kelley et al. (2009) did not use a validated stool scoring system, which reduces the clinical relevance. Due to the partial relevance to the PICO and the limitations, these studies may not be adequately strong enough to support a faster clinical recovery by the probiotic supplement.

Two studies (Gomez-Gallego et al., 2016 and Ziese et al., 2018) measured improvement in diarrhoea severity in the probiotic group. Gomez-Gallego et al. (2016) reported a greater improvement in stool consistency score in the probiotic group $(-1.712)$ than the placebo $(-1.279)$ on day 7 . However, the improvement in the probiotic group differed from the placebo by 0.433 only. With a $<0.5$ difference in the consistency score, it is questionable if there was an observable difference in the stool quality. The clinical relevance of the minor improvement in the consistency score (i.e. whether the clinical impact is noticeable in daily practice) was therefore debatable. Gomez-Gallego et al. (2016) did not evaluate the baseline variations, such as sex, age and breed, between the probiotic and placebo group. The potential baseline variations may confound the observed difference. Meanwhile, Ziese et al. (2018) reported that the probiotic group took one day less to achieve a statistically significant improvement in the Canine Haemorrhagic Diarrhoea Severity Index (CHDSI). The clinicians and owners may have different standards when they evaluate the costs and benefits of a one day improvement. It was then challenging to comment on the clinical relevance of Ziese et al.'s (2018) finding.

The probiotic group presented a greater decrease of faecal $C$. perfringens on day 7 (Gomez-Gallego et al., 2016), and a lower abundance of faecal $C$. perfringens (Ziese et al., 2018). Ziese et al. (2018) did not explain the inconsistent number of faecal samples analysed on day $0,7,21$. The clinical relevance of these finding is affected by the undefined relationship between $C$. perfringens and acute diarrhoea. Guard et al. (2015) reported an association between increased $C$. perfringens in faeces and acute diarrhoea, whilst Duijvestijn et al. (2016) could not find an association between them. Hence, it remains controversial whether a reduction of $C$. perfringens in faecal samples can be regarded as a clinical benefit.

Nixon et al. (2019) and Kelley et al. (2009) showed a lower percentage of dogs in the probiotic group received additional treatment, such as antibiotics, than the placebo group. The data presented by Kelley et al. (2009) is 
of limited strength as no statistical analysis was performed. In contrast, Nixon et al. (2019) offered fairly strong evidence by the inclusion of a large sample size $(n=118)$. The signalment between the two groups was comparable. One issue with Nixon et al. (2019) is the partial relevance to the PICO (as discussed previously). Nonetheless, one study provided fairly strong evidence that there is a reduced requirement of additional treatment (e.g. antibiotics) in dogs administered a daily probiotic. Further studies are helpful to validate this suggested benefit and to completely address dogs that have acute diarrhoea with no identifiable cause.

In conclusion, five placebo-controlled trials partially or completely addressed the PICO. The participating dogs were recruited from clinics, which support the applicability of these studies. They all presented a better clinical improvement in the probiotic group than the placebo. This suggests a daily supplement of oral probiotic may provide better clinical outcomes to dogs having acute diarrhoea without an identifiable cause. However, the clinical relevance of the reduction in faecal $C$. perfringens and improvement in diarrhoea severity were uncertain. The strength of the studies supporting a shorter time to diarrhoea resolution was limited due to the partial relevance to the PICO and several limitations. Lastly, Nixon et al. (2019) offered fairly strong evidence for a reduced requirement of additional treatment in dogs administered a probiotic. Additional studies would be beneficial to validate the better clinical outcomes brought by probiotic supplementation.

It is worth noting that the probiotic agents, dose, dosing interval, the methods of feeding, diets and the duration of treatment in these studies were varied. Clinicians or owners need to be aware that these variations can lead to different clinical outcomes.

\section{Methodology Section}

\begin{tabular}{|c|c|}
\hline \multicolumn{2}{|l|}{ Search } \\
\hline $\begin{array}{r}\text { Databases searched and dates } \\
\text { covered: }\end{array}$ & $\begin{array}{l}\text { CAB Abstracts on OVID Platform } 1973 \text { - Week } 182019 \\
\text { PubMed } 1973-2019 \\
\text { Web of Science } 1900-2019\end{array}$ \\
\hline Search strategy: & $\begin{array}{l}\text { CAB Abstracts: } \\
\text { (Dog* or cani* or bitch* or pupp*) and (Diarrhoea or diarrhea or } \\
\text { gastroenteritis or enteritis or scour or dysentery or loose stool or } \\
\text { faeces or colitis) and (Probiotic* or lactobacill* or bifidobacteri* or } \\
\text { enterococc* or lactic acid bacteri* or lactic acid producing bacteri*) } \\
\text { PubMed and Web of Science: } \\
\text { (Dog or dogs or cani* or bitch* or pupp*) and (Diarrhoea or diarrhea } \\
\text { or gastroenteritis or enteritis or scour or dysentery or "loose stool" } \\
\text { or faeces or colitis) and (Probiotic* or lactobacill* or bifidobacteri* } \\
\text { or enterococc* or "lactic acid bacteri*" or "lactic acid producing } \\
\text { bacteri*") }\end{array}$ \\
\hline Dates searches performed: & $15^{\text {th }}$ May 2019 \\
\hline
\end{tabular}




\begin{tabular}{|l|l|}
\hline Exclusion / Inclusion Criteria & \\
\hline Exclusion & Papers not in English \\
& Paper cannot be accessed \\
& Not relevant to the PICO, e.g. did not involve dogs with acute \\
diarrhoea, probiotic administrated in ways other than oral route, \\
diarrhoea with an identifiable cause. \\
& Reviews \\
& Single case reports \\
& Conference papers \\
& Book chapters \\
\hline Inclusion & Any relevant primary research paper discussed the clinical impacts \\
& brought by daily oral administration of probiotic to dogs that have \\
& acute diarrhoea without an identifiable cause. \\
\hline
\end{tabular}

\begin{tabular}{|c|c|c|c|c|c|c|c|}
\hline \multicolumn{8}{|c|}{ Search Outcome } \\
\hline Database & $\begin{array}{c}\text { Number } \\
\text { of } \\
\text { results }\end{array}$ & $\begin{array}{c}\text { Excluded - Case } \\
\text { reports, } \\
\text { conference } \\
\text { papers, reviews, } \\
\text { book chapters, } \\
\text { correspondence }\end{array}$ & $\begin{array}{l}\text { Excluded } \\
\text { - Not } \\
\text { relevant } \\
\text { to PICO }\end{array}$ & $\begin{array}{l}\text { Excluded - } \\
\text { Languages } \\
\text { other than } \\
\text { English }\end{array}$ & $\begin{array}{l}\text { Excluded - } \\
\text { Inaccessible }\end{array}$ & $\begin{array}{l}\text { Excluded - } \\
\text { Duplication }\end{array}$ & $\begin{array}{c}\text { Total } \\
\text { relevant } \\
\text { papers }\end{array}$ \\
\hline $\begin{array}{l}\text { CAB } \\
\text { Abstracts }\end{array}$ & 365 & 39 & 317 & 5 & 0 & 0 & 4 \\
\hline PubMed & 317 & 10 & 302 & 0 & 0 & 4 & 1 \\
\hline $\begin{array}{l}\text { Web of } \\
\text { Science }\end{array}$ & 172 & 3 & 165 & 0 & 0 & 4 & 0 \\
\hline \multicolumn{7}{|c|}{ Total relevant papers } & 5 \\
\hline
\end{tabular}

\section{CONFLICT OF INTEREST}

The author declares no conflicts of interest.

The author would like to thank Dr Louise Buckley for her guidance in knowledge summary writing. 


\section{REFERENCES}

1. Chandler, M. (2002). The chronically diarrhoeic dog. In Practice, 24(1), 18. DOI: 1136/inpract.24.1.18

2. Duijvestijn, M., Mughini-Gras, L., Schuurman, N., Schijf, W., Wagenaar, J., \& Egberink, H. (2016). Enteropathogen infections in canine puppies: (Co-)occurrence, clinical relevance and risk factors.Veterinary Microbiology, 195, 115-122. DOI: 1016/j.vetmic.2016.09.006

3. (2018). QuickCalcs. Retrieved from https://www.graphpad.com/quickcalcs/contingency1.cfm

4. Guard, B., Barr, J., Reddivari, L., Klemashevich, C., Jayaraman, A., Steiner, J., Vanamala, J., \& Suchodolski, J. (2015). Characterization of Microbial Dysbiosis and Metabolomic Changes in Dogs with Acute Diarrhea.PLOS ONE, 10(5), e0127259. DOI: 1371/journal.pone.0127259

5. Gómez-Gallego, C., Junnila, J., Männikkö, S., Hämeenoja, P., Valtonen, E., Salminen, S., \& Beasley, S. (2016). A canine-specific probiotic product in treating acute or intermittent diarrhea in dogs: A doubleblind placebo-controlled efficacy study.Veterinary Microbiology, 197, 122-128.

DOI: 1016/j.vetmic.2016.11.015

6. Herstad, H., Nesheim, B., L'Abée-Lund, T., Larsen, S., \& Skancke, E. (2009). Effects of a probiotic intervention in acute canine gastroenteritis - a controlled clinical trial.Journal Of Small Animal Practice, 51(1), 34-38. DOI: 1111/i.1748-5827.2009.00853.x

7. Kelley, R. L., Minikhiem, D., Kiely, B., O'Mahony, L., O'Sullivan, D., Boileau, T., \& Park, J. S. (2009). Clinical benefits of probiotic canine-derived Bifidobacterium animalis strain AHC7 in dogs with acute idiopathic diarrhea.Veterinary therapeutics: research in applied veterinary medicine, 10(3), 121-130. DOI: $\underline{5167 / \text { uzh-31198 }}$

8. Nixon, S.L.,Rose, L., \& Muller, A.T. (2019). Efficacy of an orally administered anti-diarrheal probiotic paste (Pro-Kolin Advanced) in dogs with acute diarrhea: A randomized, placebo-controlled, double-blinded clinical study. J Vet Intern Med, 33, 1286-1294. DOI: 1111/jvim.15481

9. Roine, J., Uusitalo, L., \& Hielm-Björkman, A. (2016). Validating and reliability testing the descriptive data and three different disease diagnoses of the internet-based DOGRISK questionnaire.BMC veterinary research, 12(1), 30. DOI: 1186/s12917-016-0658-z

10. Ziese, A., Suchodolski, J., Hartmann, K., Busch, K., Anderson, A., Sarwar, F., Sindern, N., \& Unterer, S. (2018). Effect of probiotic treatment on the clinical course, intestinal microbiome, and toxigenic Clostridium perfringens in dogs with acute hemorrhagic diarrhea.PLOS ONE, 13(9), e0204691. DOI: 1371/journal.pone.0204691 


\section{EVIIDEFeE

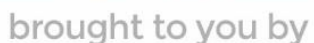 \\ RCVS KNOWLEDGE}

\section{Intellectual Property Rights}

Authors of Knowledge Summaries submitted to RCVS Knowledge for publication will retain copyright in their work, and will be required to grant RCVS Knowledge a non-exclusive license to publish including but not limited to the right to publish, re-publish, transmit, sell, distribute and otherwise use the materials in all languages and all media throughout the world, and to license or permit others to do so.

\section{Disclaimer}

Knowledge Summaries are a peer-reviewed article type which aims to answer a clinical question based on the best available current evidence. It does not override the responsibility

of the practitioner. Informed decisions should be made by considering such factors as individual clinical expertise and judgement along with patient's circumstances and owners' values. Knowledge Summaries are a resource to help inform and any opinions expressed within the Knowledge Summaries are the author's own and do not necessarily reflect the view of the RCVS Knowledge. Authors are responsible for the accuracy of the content. While the

Editor and Publisher believe that all content herein are in accord with current recommendations and practice at the time of publication, they accept no legal responsibility

for any errors or omissions, and make no warranty, express or implied, with respect to material contained within.

For further information please refer to our Terms of Use.

RCVS Knowledge is the independent charity associated with the Royal College of Veterinary Surgeons (RCVS). Our ambition is to become a global intermediary for evidence based veterinary knowledge by providing access to information

that is of immediate value to practicing veterinary professionals and directly contributes to evidence based clinical decision-making.

https://www.veterinaryevidence.org/

RCVS Knowledge is a registered Charity No. 230886.

Registered as a Company limited by guarantee in England and Wales No. 598443.

Registered Office: Belgravia House, 62-64 Horseferry Road, London SW1P 2AF

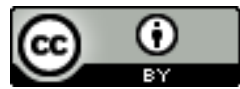

This work is licensed under a Creative Commons Attribution 4.0 International License 